\title{
Politics of Religion in Tehmina Durrani's Blasphemy
}

\author{
Nouman Tahir \\ Student of BS English, GPGC, Karak \\ Syed Hanif Rasool \\ Assistant Professor, Khushal Khan Khattak University, Karak
}

\begin{abstract}
Generally regarded as one of the most influential factors in the human history, religion has frequently been used as a strong political force by the ruling pundits. In the hands of retrogressive elites, religion has often been operated as an aggressive tool to subdue the voices of the common. In the recent political history of the subcontinent, the aforementioned political role of religion can hardly been overemphasized. Made on the rhetoric of Islam, Pakistan has frequently identified herself as Islam ka Qilla (fortress of Islam) since the very inception till date. Such a monolithic approach of religion has substantially shaped the individual and collective socio-political consciousness of people in Pakistan. Driving the country's contemporary sensitivities, the politics of religion pivots Pakistani society. The contemporary English fiction in Pakistan largely represents the cultural issues, deeply rooted in religion. Tehmina Durrani, one of the most acclaimed Pakistani novelists, frequently writes about the religiosity and the status of women in Pakistan. Setting against this socio-political preference of religion in Pakistani society, it is proposed that Tehmina Durrani's Blasphemy can be read as a critique of the retrogressive roles of clergy and aristocracy in Pakistan. Highlighting Pakistan's patriarchal and religious society, it is contended that Blasphemy is a realistic representation of the wretched conditions of women. Investigating the politics of religion in Pakistan's rural setting, the paper foregrounds Tehmina's bold stance on issues of women in the harsh social conditions caused by the nexus of retrogressive clergy and oppressive feudal aristocracy.
\end{abstract}

Key Words: Politics of religion, retrogressive clergy, oppressive feudal aristocracy, patriarchal society.

(I)

'History should be asked who has been the biggest forces of human casualties out of battlefield, indeed its fingers will rise towards the courtesies that were established in the name of religion and law' (Azad 148).

Religion has been relatively considered as a substantially influential socio-political driving force since time immemorial. Throughout history and our lives, religious tags are always there with us. 
Human race has been generally engaged in two endeavors: exploitations of the material resources for sustainable living and metaphysical pursuits for spiritual satisfaction. Thus, religion is believed to be divine guidance through God's messengers and prophets who were regarded as the role models by a great majority of people all over the world through ages. Owing to its importance in the lives of individuals and in the manners and rites of group, religion gradually overwhelms every aspect of human society and ultimately becomes a tool in the hands of the rulers in the theocentric premodern world. With the emergence of modern world, and with a remarkable evolution in the human thought and action, the world, particularly the West, saw a substantial shift from theocentric pattern to anthropocentric mould and soon enables itself to get out of the religion's power spell initially with the Renaissance and then exhaustively with the French Revolution. However, in the East religion remains a most influencing factor transforming almost every aspect of its societies and being used by its rulers to subjugate people in their individual and collective lives, thereby emerging as an overwhelming force to maneuver the political and social spheres. In the subcontinent, the church's political role of medieval India continued by the colonial master who gave more importance to the Pirs and gaddinasheens. As a result of the two-Nation Theory, Pakistan emerges as Islam Ka Qilla (Fortress of Islam) and thereby the religious Pirs and pundits have niched a substantial position in influencing the state's policies. Whereas the state has been using the religious stratum -- owing to their close connection to the masses-- for her own projects during and after the Cold War, these Pirs and gaddinasheens have havocked the country's illiterate, ignorant, and dependent masses and have exploited the religious feelings of the laity.

Durrani's Blasphemy is the representation of the aforementioned violation of religion. Since religion has been vividly used for political purposes in the country, several writers approached the subject through their fictional rendering of such misuses. Attempts of such authors have been discouraged and their work has been regarded as controversial by the state and her proxies. Blasphemy is one such narrative of the power of religion in Pakistan that is regarded as controversial due to its bold depiction of the ills of the custodians of religion. The novel disinters the wrongs these Pirs have perpetrated under the guise of Islam.

Pakistani English novelists have touched upon a wide range of subjects for their fictional rendering. Durrani belongs to the generation of bold female voices who uncompromisingly have highlighted the issues that have rarely been depicted in Pakistani English fiction. Overwhelmed with women issue, Blasphemy attempts to provoke women's attention towards their rights and it highlights repulsive behavior of the clergy and feudal lords. While investigating the true face of the aforementioned classes, Durrani foregrounds the miserable tales-- mainly of the poor working class women -- speaking a lot about the harsh realities of the common people. Blasphemy reveals how the miserable women suffer due to the misinterpretation of religious injunctions by the Pirs and gaddinasheens. 
Durrani, herself is a Pakistani women's rights activist has authored a controversial autobiography, My Feudal Lord (1991). In that monograph she sensationalizes her traumatic marital life by demeaning her former husband, a Pakistani politician, Ghulam Mustafa Khar. She ascribes her sufferings to the patriarchal and feudal set up in Pakistan where religion is used by the tyrants for their vested interests. Preoccupied with the harsh conditions of women in Pakistani society, she attempts to emphasize the notion that how male has often seen religion as a tool to subjugate women. She, therefore, frequently writes about the religiosity and status of women in Pakistan to provoke attention of the people to the widespread and deep-rooted religious corruption.

Whereas religion as a moral phenomenon is progressive, religion as a political motive, by and large, has been retrogressive. Britannica Concise Encyclopedia defines religion as a 'relation of human beings to God or the gods or to whatever they consider sacred or, in some cases, merely supernatural' (online). Contrary to the aforementioned peripheral role of religion in the West, South Asian states tend to see religion as a powerful tool to manipulate their societies, maneuver their masses and exploit the poor and illiterate on the sacred name of religion. The Pirs and gaddinasheens reiterate their previous manipulating role in the contemporary postcolonial times. These Pirs on one hand work as the state proxies and on the other hand establish themselves as the sole custodian and interpreters of religious injunctions. On the name of religious missions, they expand their own material interests and fulfill their carnal desires. Blasphemy reveals their retrogressive role in society.

Blasphemy focuses on the dark sides of the apparently religious acts of these religious elites who exploit individual and collective lives of the common people. It represents the wretched condition of women under Pakistani patriarchal and religious society. The story is narrated through first person. The character of Heer tells us the tales of suffering. She is married at the age of fifteen to a Pir of her father's age whose religious persona is venerated in the entire village. The marriage proves to be a horrid dream for Heer. The promiscuous and unprincipled sexual life of the Pir and his licentious nature has ruined her innocent imagination. The heinous crime of the Pir has shattered her belief in the good and noble. The ignoble acts of the Pir has shattered her life. Since the fake noble persona of the Pir is unquestionable and she is unable to stand against the Pir's evil. She is helpless and alone because the Pir can prove her wrong by virtue of his exalted religious status. Blasphemy uncovers the religious exploitation and oppression of the Pir and the retrogressive social conditions of the rural Pakistan which is mainly under the influence of the exploitive religiosity.

(II)

Whereas this study hypothesis that Blasphemy foregrounds the tyrannous role of the pirs in Pakistani society, several scholars have approached the novel from psychological and feministic stand-points. Adiba Iqbal in her article "Deterioration of Self, Emotions and Islamic values: A Critical Survey of Tehmina Durrani's Blasphemy' focuses upon the death of emotions and 
Islamic values in the society. She argues that "[e]motional death is the result of extraordinary stressful events" shattering one's "sense of security" making one feels "helpless and vulnerable in a dangerous world" (210). Emphasizing "the emotional death of Pir Sain's wife Heer and the emotions of all the people who blindly follow" Pir, Iqbal argues the deterioration of Islamic values due to the luscious exploitation of Pir Sain cleverly concealed under the guise of Islam. Iqbal reveals how Pir misuses the name of Islam by dishonouring and molesting innocent women.

Asma in her article, "Loss of Essential Humanity and Empathy as a Result of Exploitations in Blasphemy. . ." argues that "Blasphemy [t]he exploitation, the suffering, the afflictions, the atrocities, the pain, the torment, the turmoil, the chaos, and most of all the loss of essential humanity and empathy as the consequence of all these give a jolt to the minds of readers"(127).

Approaching Blasphemy from feminstic viewpoint, Bharti Dave regards the novel as 'Chilling Wails'(45). Quoting Fareda Hussain in her article, "Chilling Wails in Blasphemy by Tehmina Durrani", Bharti writes that "[t]alking about Islamic countries in whole, subjugation of women is not new for them. It has emanated from the feudal structure in pre-Islamic societies. This society always had father as a ruler of the family unit and wives and daughters were referred to interchangeably as slaves"(46).

Sandeep Rani in her paper, "Women and Religion in Pakistan: A critical Analysis of Tehmina Durrani's Blasphemy. . ." argues that "women victimization is one of the evils confronting women all over the world" and Pakistani society "is no different from any other male obsessed society"(80). She emphasises that Pakistani women are so "vulnerable" that they can easily become "targets of any form of oppression, humiliation, deprivation and discrimination" in the traditional "patriachal social system" using "religion" as a medium of exploitation and disinheriting the women "from all rights" by "silencing their voice"(80). She adds that religion is "associated with God and goodness" and in principle it must treat "men and women in equal terms with humanity and humility", but under "the patriarchal system", "the mediators" like Pir Sain exploits religious authority, humiliating, degrading, victimising and subjugating women (80).

Highlighting the issues of feudal and patriarchal domination in Pakistani society, the aforementioned critics have emphasized the subversive tone of the novel flagging people's suffering due to exploitation perpetrated against them. However, everyone scrape the notions of the root cause which make the innocent people vulnerable. It is further intended to expose the root cause of such victimization by the hands of pirs.

(III)

"There are those who call themselves Muslim, but their interpretation of Islam is far more dangerous than threats from infidels" (Shafaq 47). 
Emphasizing the notion that the innocent laity has always been under the strong spell of the clergy, this paper uncovers the latter's exploitative and influential role of religion in Pakistani society. Highlighting the overwhelming role of religion in subcontinent, Blasphemy affirms that the politics of religion still haunts the subcontinent and it has been one of the strongest impediments in the way towards civility and development. It is not only the misuse of religion which influences people and causes them atrocity. There are so many other factors which have impacts upon people, especially in developing countries like Pakistan, the rate of illiteracy, lack of proper education, people's mental growth, poverty, "[t]heir poverty imprisoned them to the shrine"(105) etc are different factors, but religion---considered to make people sacralize made diverge. It became the worst experience for those who didn't understand it and their lakeness to this lead them toward the sordid aspect of life. This ignorance of the people lead one person to govern their emotions and passions. Referring to the clergy's doing, Toti, a ghost, says: "[t]hey are impostors, imposed upon our hearts. They exploit our ignorance, our poverty, our losses and our limitations to rule over us" (88).

Spotlighting the cruelty of clergy, Blasphemy recounts how the Pir Sain's haveli has witnessed brutish tales bringing pain suffering upon the miserable laity. Uncovering the vicious inner world of the Pir and foregrounding his use of religion for his material and carnal desires, Durrani brings Heer, the wife of Pir Sain, as a collective mouthpiece narrating the often sidelined stories of the common people of the village who regard the shrine as a symbol of spiritual blessings. Heer regards such a "shrine" powerless without the common people (106). Some critics regard Blasphemy as a controversial narrative loaded with exaggerated elements, when an ordinary man will read it (s) he will hardly agree with some incidents but Durrani herself affirms a statement introducing her novel: "This novel is inspired by a true story. Names and certain events have been altered to protect the identity of the woman whose story this is" (5).

Alongside the name given to the novel "Blasphemy", it kicks off with a religious ritual of Islam, the call to prayer (Azaan)," Allah ho Akbar, Allah ho Akbar, ashudo an la illaha illallah" (11), bespeaking motif of the story. Considering the South, particularly Pakistani society is under such religious spell that they can not marginalize between the believers and they believed. "Pir Sain" governs "trapped people" (61). "Consider[ing]" him "to be a direct link between the Almighty and the wretched", they have assigned the prerogative of their fate to him, "believ[ing] that his intervention could even alter what Allah had fated for them"(61). Thus it became common fallacy among them. True believers did not need any link for their connection with God. The instance is clear from the story of Sakhi Bibi who did not pray to Pir Sain even when her son was on death bed. She and her husband only believe in Allah, as when someone advises her to get blessing of Pir Sain, she told them all the times, "I have faith only in Allah"(106). This story investigate that the exposition is not about Islam but on the way people use it for their offenses. Only some were against the shrine. 
Explaining their uncanny nature, Amma Sain told Heer, "We are the direct descendants of the Prophet. The power of the shrine is fourteen hundred years old. It cannot be challenged" (61). Late on the statement is questioned by Toti as, "[d]o their actions in any way reflect our Prophet's greatness"'(88)?

Durrani presented the picture of the shrine as an eye opener to the outsiders. She reveals to the whole world that how they blur the illuminate portrait of Islam. "The whims of" their "pir spurned the message of God. He practised another religion"(83). No matter how beautiful Islam as a religion is, but in Blasphemy, it is treated with such contempt by its very preachers. Islam in any sense does not direct any one to practice what these Saints are practicing. They have a selfmade religion of their own, for which they met time and again to retrospect and safeguard their insecurities. They preach for their interests only, "Religious leaders from across the country had assembled to discuss which injunctions best suited their interests"(103).

Highlighting the religiously privileged status of Pir Sain, the novel recounts a scene in which the former's devotees are so blinded by their false system of beliefs that Heer's mother instructs her daughters that they should not "cover" their "faces before Pir Sain" for "he is too holy for that"(24). Similarly, in another scene, when the Pir Sain has died, Rajaji (his second son) occupies his father's gaddi (spiritual throne). After the latter's dastarbandi (a ceremony of wearing the turban of the deceased), his "grand aunts, too old to even stand up, bent low to touch the feet of the new pir" (188). Perplexed by such an exaggerated reverevence contrary to the true spirit of Islam, Heer regards, "Pir sain and Allah" extremely opposite poles "to follow"(157). Where on one side Ma consider pir as "strick purdah" observer and "deeply religious"(25) and according to Dai, he was the "chosen one". "He knew how to save the faith from blasphemers"(101) while Heer regards him as "a symbol of munafiqat" herself "a soldier" and her struggle for life "a jehad"(181).

Emphasizing the immeasurable amount of distress and hardship Heer has gone through, Durrani recounts the redemptive state of Heer's mother regretting her decision of marrying Heer to Pir Sain."[P]aranoid about her status"(23) after her husband's death, Ma sees the only hope of sustainable living in marrying Heer to Pir Sain. Ma believes that this marriage will bring prosperity to the entire family and will end their poverty. Ironically, Ma regards the marriage proposal of Pir Sain for Heer as a turn in their "destiny" and she envisions her household "among the privileged"(26) ones, but in reality the marriage proved to be a total fiasco playing havoc with Heer's life. Later on after the marriage, Heer's life comes under the spell of unimaginable sufferings and no one, even her mother, is unable to help Heer to overcome her grief and get out of quagmire of the toxic relationship with Pir Sain. After Heer's death, Ma in the angst of deep regrets, prays to God to forgive the latter for sending her child to Pir Sain's household seemingly considered to be holy, but in reality a hell, not only for Heer but for everyone who is part of the Pir Sain's haveli (227). Durrani's identification of the haveli with "hell" also implies the death of Heer under unbearable torments. 
To Heer, Pir Sain's reality is totally different from the general noble perception of the people about him. Heer has fully realised the dark side of Pir Sain's vexing character. Contemplating on the reality of Pir Sain's heinous shadow guised under his pious persona of a mystic, Heer asks herself, "was his life inside the Haveli really not known outside it?" Was this horrible man is the one is known only to me or the ignorant people who adore him also know Pir sain's real character? (65). Witness to the evil side of Pir Sain "camouflaged" by his white starched cotton(65), Heer recounts the latter's true brutal self:

"[t]o me, my husband was my son's murderer. He was also my daughter's molester. A parasite nibbling on the Holy Book, he was Lucifer, holding me by the throat and driving me to sin every night. He was bhai's destroyer, Amma Sain's tormentor, Ma's humbler and the people's exploiter. He was the rapist of orphans and the fiend that fed on the weak. But over and above all this, he was known to be the man closest to Allah, the one who could reach Him and save us"(143).

Recounting another story of Sakhi Baba's only child who suffers from a disease which no doctor can investigate; Durrani further unfolds Pir Sain's character. Sakhi Baba and his wife are against the shrine and thereby they do not believe in his Pira geri. In a scene in the novel, one aft soon, Sakhi Baba's wife becomes desperate and seeks Pir's blessings for his child. Pir Sain tells her that they are "too late"(106). Upon this rude response from Pir Sain, Sakhi's wife feels regret on visiting the shrine, realizing her mistake, she prays to God to forgive her "for coming here" (107).

Blasphemy, on the one hand, epitomizes the character of a corrupt mystic exploiting people's emotions for his carnal desires under the guise of religion, on the other hand, it exposes the ignorance and superstitions of the laymen in the matters of religion. Explaining the notion how Pir Sain increases his wealth and power by receiving the offerings and donations from the wealthy mureeds (devotees/followers of a pir), the novel recounts Heer's remarks on such a lucrative relationship between Pir Sain and his mureeds. She says, "[e]ven influential and wealthy men set at his feet like ordinary followers. Pressing his legs in reverence, they implored him to pray for successful deals, licenses and sanctions to come through"(63). Highlighting the role of the so-called spiritual leaders, Heer emphasizes the growing stock of Pir Sain's wealth given to him by his devotees as reward for the former's recommendation and favor of the latter's various issues and works before God. These rewards also include things like Land Cruiser, Lancer and Pajero etc. The filthy rich businessmen and corrupt politicians have given Pir Sain secret funds which the latter utilize to strengthen his political nexus. The glittering of Pir Sain's accumulated wealth has blurred sight of Heer's mother and when the former sends a marriage proposal to the latter's daughter, the latter instantly agrees to that. Attempting to convince her daughter for the aforementioned proposal, Heer's mother remarks, "[t]hese people are very wealthy. They are far above our status. It is a great honour that they should even visit us. Look at us, she said, waving her hand around. 'What do we have to offer them'?'(24). Pir Sain's real 
face is exposed after the marriage and Heer laments at her bad luck. Thinking about Pir Sain's wealth and status, Heer seems baffled by the unusual respect and honour given to Pir Sain by his devotees. In utter confusion, she asks herself such question, "Did Pir Sain have supernatural power or was it faith bestowed upon him by ignorant people?. . Was his life inside the Haveli really not known outside it?. . Was the man in my bedroom a man only I knew?"(65). She thinks "The shrine is a symbol of all exploitation. If men can use Allah against the weak, all other means are lesser and easier to exploit. If we make a war against this shrine, every truth will be served" (196).

Heer's character also serves a major purpose of exposing Pir Sain's heinous crimes committed under the noble guise of the Shrine. Spotlighting how Heer attempts to defy Pir Sain's fake role as spiritual guru and as a noble custodian of the Shrine, Durrani recounts a scene in which Pir Sain's heir, Rajaji, intends to marry Maharani (an illegitimate daughter of Pir Sain). To protect sanctity of the Shrine, Sakhi bibi, a folk, requests Heer to save the Shrine from the curse of such an unethical and illegitimate marriage. Responding to Sakhi bibi's concern, Heer refers to the felonious character of Rajaji and regards the latter as "a link to a satanic chain" of his father, Pir Sain (208). Heer further argues that why Sakhi bibi expects "him to adhere to Allah's will? Which law of Islam is observed here that this one should not be broken? This is not the only sin, nor is it the worst. Let the myth shatter and the filth spill over"(208). Towards the end of the novel, Heer offers herself to God to allow her to use herself "to expose" the Pir Sain's evils concealed behind the holiness of the Shrine(197). She affirms "to take a course" that will condemn her but "expose the distortion" of Allah's message at the hands of His "enemies"(197).

In Blasphemy, Durrani exposes the exploitative, promiscuous and unprincipled lives of of the so called pirs. Attempting to expose the aforementioned dark side of the so-called spiritual leaders and mystics, revealing their heinous crimes through, she recounts how Sikhi baba and his wife, standing firm against the Haveli and its false blessing, openly criticize the Pir Sain and his son after their own child's health had been restored by the grace of God, not by any of the Pir Sain's so-called spiritual power. Preventing innocent people from the latter's trap, Sakhi baba speaks:

"By giving our son life, Allah conforms that those at the Shrine are impostors reveling in lies. Saints need no money, no favour, and no subjugation to pray for you. . . The rulers of the Shrine run a business in Allah's name. You have made it lucrative. . You are the source of their power. . You strengthen Satan. . .You distort Islam. . .Do not walk barefoot with your meager resources to worship graves instead of Allah. . God is where you are... The god the pir worships is one who approves of him.

Our God does not" (107-8).

Towards the end of the novel, Durrani explicitly recounts how Heer's mission has been fulfilled when a character in the novel remarks posthumously about the latter's struggle against the tyrannous After one year of her death a woman stood near her tomb, praying, "O Allah, bless 
this soul for exposing the decadence of Shrine worship. Bless her for bringing us closer to you" (229).

\section{(IV)}

In Blasphemy, Durrani deals with the oppressive role of the clergy exploiting the innocent and illiterate folk. She also foregrounds the poor condition of the rural Pakistani woman humiliated and exploited by the pirs and the feudal lords. The contemporary English fiction in Pakistan largely represents the cultural issues, deeply rooted in religion; therefore, Durrani is read as a critique to the prevalent system of rural rulers using religion as a merely exploitative means. Whereas Pakistan's ideologues since its creation, have identified the country as Islam ka Qilla (fortress of Islam), but Pakistan's state, from the very beginning till date, has used religion as a political slogan to attract the nation, but in terms of the practical implementation of the most important injunction, there is wide gap between the perception and reality. The society is intentionally kept blind to the real meaning of Islam, therefore, politics of religion still drive Pakistani society. Keeping in view Pakistan's patriarchal and religious societies, it has been argued in this article that Blasphemy is the most realistic image of the wretched conditions of women deprived of their due rights by the morally corrupt clergy grown under the shades of feudalism. The country's ruling elites and their compadres such as the exploitative clergy and the feudal lords, taking advantage of innocence of the masses, have used religion against the common people to suppress the latter's voices. It has been attempted to foreground Tehmina's bold stance on the issues and problems of women caught in the harsh social conditions caused by the nexus of retrogressive clergy and oppressive feudal aristocracy.

\section{Works Cited}

Azad, Abul Kalam. Umm Ul Kitab (Urdu), Lahore: Makki Dar ul Kutub, 1990

Durrani, Tehmina. Blasphemy, Lahore: Feroz Sons (Pvt.)Ltd. 1998

Durrani, Tehmina. My Feudal Lord, London, Corgi edition, 1995

Iqbal, Adiba. et all. "Deterioration of Self, Emotions and Islamic values: A Critical Survey of Tehmina Durrani's Blasphemy" in Asian Journal of Social Sciences \&amp; Humanities Vol. 3(3) August 2014.

Shafaq, Elif. Forty Rules of Love, London, PENGUIN BOOKS, 2011.

Rani, Sandeep. Women and Religion in Pakistan: A critical Analysis of Tehmina Durrani's Blasphemy; A Novel. ISSN No. 2394-0344. Issue $2^{\text {nd }}$ July 2015

Dr. Dave, Bharti. Chilling Wails in 'Blasphemy' by Tehmina Durrani in IOSR Journal of Humanities and Social Sciences, volume 2, Issue 11, November 2017.

Mubarik, Asma. Loss of Essential Humanity and Empathy as a Result of Exploitation in Blasphemy by Tehmina Durrani in Advances in Languages and Literary Studies, vol 6, no. 3; June 2015. 
@ 2017 by the author. Licensee University of Chitral, Journal of Linguistics \& Literature, Pakistan. This article is an open access article distributed under the terms and conditions of the Creative Commons Attribution (CC BY) (http://creativecommons.org/licenses/by/4.0/). 